\title{
Development of Character Strength Training Module for Satpol PP Bandung
}

\author{
${ }^{1}$ SUSANDARI, 2 MAKMUROH SRI RAHAYU, ${ }^{3}$ RIA DEWI ERYANI \\ 123 Fakultas Psikologi Universitas Islam Bandung, Jl. Tamansari 1 Bandung \\ email: 1 susandari@unisba.ac.id; 2makmurohsrir@yahoo.com; 3riadewieryani@yahoo.com
}

\begin{abstract}
SATPOL PP (Civil Service Police Unit) Bandung have big challenges in doing their job. The challenges come not only from external factors, such as the resistance of the street vendors, but also from internal factors such as conflicts among members. It requires character support for achieving success in performing their duties. The previous research found that members of SATPOL PP Bandung have five dominant characters, which are Keberagamaan (Spirituality), Kebersyukuran (Gratitude), Motivation (Hope), Teamwork, and Justice. To achieve well-being condition and doing their job effectively, a module consists of those five characters was created. The purpose of this study was to compare the comprehension of SATPOL PP Bandung on those characters; between, before, and after the Character Strength Training. The method used was comparative and the results of the module test showed significant differences in comprehension for character Keberagamaan, Kebersyukuran, Motivation, and Teamwork, while the character of Justice did not show any significant differences between, before, and after the training. This is occurred because SATPOL PP Bandung only follow the procedures and directions from their Superiors in doing their job and are not allowed to take other actions besides the policy.
\end{abstract}

Keywords: character strength, SATPOL PP Bandung

\section{Introduction}

The challenges faced by the Civil Service Police Unit (Satpol PP) in Bandung are not easy. They are expected to enforce the rules set by the Government of Bandung in maintaining cleanliness, keeping the beauty of the city, and establishing order. In performing their duty to uphold regional regulation, SATPOL PP Bandung should avoid violence, which becomes the reason they are not armed. However, there are many obstacles faced by members of the SATPOL PP Bandung in the field where they often experience external conflict as a result of street vendors' resistance that leads to the acts of aggression applied by the authorities. Sometimes, the conflicts can also occurred within the SATPOL PP Bandung members as a result of sympathy for the plight of street vendors. Therefore, specific characters are needed to support SATPOL PP in carrying out their duties. Based on the research result by
Makmuroh Sri Rahayu, Susandari, and Ria Dewi Eryani, the profile of Tough Personal (Character Strength) member of Civil Service Police Bandung in Town Square Bandung, found five dominant characters of Spirituality, Gratitude, Fairness, Hope, and Citizenship, called Signature Strength.

In Positive Psychology approach, to get the well-being of individuals at work, one needs to optimize the predominant code called Signature Strength (Peterson \& Seligman, 2002). Similarly, in a group, there is a dominant character owned by majority of its members.

One way to optimize Signature Strength of SATPOL PP Bandung members is to provide training that aims to make them aware of the strength characters they should have in order to be used optimally in their duties. Before conducting the training, modules need to be made and members will be tested according to the modules. 


\section{Method}

In the early stages of this research, there was a questionnaire asked to identify the dominant character owned by members of the SATPOL PP Bandung. It resulted in five dominant characters (Signature Strength) include: (1) Spirituality, which is a strong faith in God and demonstrated by the activity of worshiping to God, (2) Gratitude, which is the feeling of grateful for every blessing given by God, (3) Fairness, which is to think, act, and treat fairly to everyone, (4) Hope, which is the positive feeling about the best results in the future and how to implement them in order to be realized. and (5) Citizenship, which is a member of a group to devise and implement obligations optimally.

\section{Positive Psychology Approach}

The goal of Positive Psychology is to change the emphasis from simply fixing the wrong things in life to build the best quality of life. At subjective level, positive psychology concerning the subject's positive experience as welfare (well-being), and satisfaction (in the past), flow, pleasure, sensual pleasure, and happiness (in the present), optimism, hope and confidence (in future). While at Individual level, it is related to the capacity to love and vocation, courage, interpersonal skills, sensibility, aesthetics, perseverance, forgiveness, originality, thinking toward the future, talent, and wisdom. At the group level concerning civic virtue and institutions that move individuals to a better social life, responsibility, caring, altruism, citizenship, moderation, tolerance, and work ethic (Gillham \& Seligman, 1999; Seligman \& Csikszentmihalyi, 2000). In the perspective of Positive Psychology, the optimization of unique character owned by the individual would provide well-being and ultimately, a good work.

It is in contrast to other approaches in conventional psychology which is only concerned about the weaknesses that must be corrected in order to deliver good work. According to the theory of Character Strength which included in the Positive Psychology, if an individual wants to improve the distinctive performance of his/her own character (Signature Strength), it should be optimized and do not grow the character that will increase the burden since it is not part of himself/herself. This also applies in the context of groups, where each group has a dominant unique character derived from majority character of the group members.

\section{Virtues, Strength, and Signature of Character Strength}

Concept of Character Strength introduced by Christopher Peterson and Martin Seligman in 2002. Definition of Character Strength is a positive trait in individuals which become a way for the release of virtue. The character meant here is a good character. Characters can be seen from the feelings, thoughts, and behaviors of individuals in a stable phase, but they but can also be formed. Another concept in this study is virtue, a universal one, which is collected from experts philosophy and religion. In this case, the Virtues are Wisdom, Courage, Humanity, Justice, Temperance and Transcendence. Each Virtue consists of characters which becomes an outlet for Virtue.

Table 1

24 Characters and Virtues

\begin{tabular}{cl}
\hline Virtues of & \multicolumn{1}{c}{ Character } \\
\hline Wisdom and & - creativity \\
Knowledge & - Curiosity \\
& - open mindedness \\
& - love of learning \\
& - perspective \\
Courage & - Bravery \\
& - persistence \\
& - integrity \\
& - vitality \\
Humanity & - love \\
& - kindness \\
& - social intelligence \\
& - citizenship \\
& - fairness \\
& - leadership \\
& - forgiveness and mercy \\
Temperance & - humility and modesty \\
& - prudence \\
& - self-regulation \\
Transcendence & - appreciation of beauty \\
& and excellence \\
& - gratitude \\
& - hope \\
& - humor \\
& - spirituality \\
\hline
\end{tabular}

Source: Christopher Peterson and Martin Seligman

Signature strength is a typical strength of individual consciousness which is shown in daily behavior. Typical strength is manifested in five dominant characters in the individual or group, while Situational Theme is specific 
habits that lead individuals to realize the power of certain characters in certain situations that might be different appeared at home and work settings, among genders, cultures, cohort, and others. In addition, the first character is not a signature strength or dominant character which can only emerged if the situation demands it.

\section{Table 2 \\ Rank of Signature Strength of SATPOL PP Bandung}

\begin{tabular}{ccc}
\hline Rank & Character & Mean \\
\hline 1 & Spirituality & 37.52 \\
2 & Gratitude & 37.33 \\
3 & Fairness & 36.14 \\
4 & Hope & 35.79 \\
5 & Citizenship & 35.59 \\
\hline
\end{tabular}

After finding the distinctive character (Signature Strength) of the members of the SATPOL PP Bandung, the next stage is to develop modules contains the dominant characters, namely Spirituality referred to Spiritualitas, Gratitude becomes Kebersyukuran, Fairness becomes Justice, Hope is motivation, and Citizenships become Teamwork. The module is tested on 24 members and performed in statistical analysis of Wilcoxon test statistics.

The purpose of this study is to see whether there is a difference or not in understanding the terms of five Signature Strength after the training sessions of SATPOL PP Bandung members. To achieve the above objectives, the method used is Comparative or Comparative Study.

\section{Intervention}

Intervention made in the Positive Psychology is intended to develop virtue and strength of the individual, not to repair or build new characters who have not previously owned. Although much virtue in Positive Psychology interventions based on spiritual and religious teachings, the intervention programs involve religious teachings are still rare. In this occasion, some of the material of strength character are prepared by incorporating the teachings of religion, in this case Islam. For example, strength character of Spirituality or Keberagamaan which is the dominant character of Satpol PP Bandung according to previous research. In many ethnic groups in Indonesia, the character of Spirituality is still upheld, including by the Sundanese. This also reveals that the culture plays a major role in determining the dominant character in a community group. Spirituality is often associated with religion. Religion of the majority of Sundanese is Islam. Therefore, the material for Spirituality character is the teachings of Islam which emphasizes there is other force outside ourselves, namely God, who has the power to regulate human life and His law must always be a reference for their action. In Islam, the religious rituals such as pray (shalat), allowing people to communicate directly with God, to thankful and ask for His help. Indirectly, the character of Spirituality which based on religious teachings can simultaneously affect other characters such as Gratitude, Hope, Teamwork, and Justice.

Gratitude character material, later renamed Kebersyukuran, was also prepared by involving religious teachings that emphasize the importance of thanking God for giving grace to humans. In addition to God, the teachings of Islam also commanded to thank fellow humans who play as an intermediary for the arrival of the saving grace. Indonesian people in general, even for the Muslim Sundanese, believes that with being grateful for what has been gained will bring more graces, like the promise of Alllah SWT that He will add pleasure if His servants be grateful.

Spirituality character can also affect the character of Hope, which stated that people should not rely too much on his ability to resolve their problems, but also involves Allah. By having the character of Hope, which is based on Spiritualitas/Spirituality, many Indonesian people are able to survive in the midst of adversity. This happen because they are not only try to solve the problem, but also hopes for Allah to help them through pray/ shalat. However, the material preparation for character of Hope in this training does not involve the teachings of Islam. The material character of Hope emphasized the importance of having goals and motivation to achieve it. The participants were asked to list his goals and mention how to achieve it.

Teamwork character could also be characterized by Spirituality which applies the teachings of religion in interaction with coworkers, subordinate or superordinate. However, in the preparation of training materials, Teamwork also does not involve religion and emphasize the importance of 
cooperation in achieving the goals. This material is mostly filled with games contains cooperation in a group

The material of Justice character is not prepared with teaching religion, although Justice in Islam is very important. The material more emphasizes on acting justly, both within the institution and external purpose of carrying out the task of enforcing the law.

\section{Result of Training}

Based on the data analysis using the Wilcoxon test statistics, the results are as follows:

Table 3

Difference Test Result After Signature Strength Training of SATPOL PP Bandung

\begin{tabular}{lll}
\hline \multicolumn{1}{c}{$\begin{array}{c}\text { STRENGTH } \\
\text { CHARACTER }\end{array}$} & $\begin{array}{c}\text { A Symp. } \\
\text { Sig } \\
\text { (2-tailed) }\end{array}$ & $\begin{array}{c}\text { CONCLU- } \\
\text { SION }\end{array}$ \\
\hline $\begin{array}{l}\text { Keberagamaan } \\
\text { (Spirituality) }\end{array}$ & 0.000 & difference \\
$\begin{array}{l}\text { Kebersyukuran } \\
\text { (Gratitude) }\end{array}$ & 0.000 & difference \\
$\begin{array}{l}\text { Motivation (Hope) } \\
\text { Teamwork/Citizenship }\end{array}$ & 0.000 & $\begin{array}{l}\text { difference } \\
\text { difference }\end{array}$ \\
Justice (Fairness) & 0.011 & $\begin{array}{l}\text { No } \\
\text { Difference }\end{array}$ \\
\hline
\end{tabular}

Alpha 0.05

Results of statistical data analysis of different test between values before and after training, as described previously, showed that the character of Keberagamaan, Kebersyukuran, motivation, and teamwork have significant differences. While the character of Justice's difference in value between, before, and after training is not significant. It is shown that all differences in values is only small or insignificant.

\section{The Results of Observations During The Training}

From the observations made by the facilitator and trainer obtained the following conclusions:

The participants are quite serious and enthusiastic in training process. This is demonstrated by many questions asked by the participants. During the discussion, the classroom atmosphere is quite alive for the participants to follow actively in discussions in discussing the case and respond to the opinion of other participants. In addition, during the training, the participants are focused and able to sit longer followed by the indoors events. All activities are strictly followed, relaxed but still attentive in training.

In training, a lot of complaints about the everyday task and job are being discussed freely and looking for the solutions. This condition causes the other participants who initially did not know the problem becomes understand of the problems faced by their peers. The superior would also be more understand of the problems of his subordinates and can directly provide a solution.

\section{Signature Strength of Satpol PP Bandung}

Spirituality, Gratitude, and Hope character belong to the Virtue of Transcendence. While Fairness and Citizenship are included in the Virtue of Justice. Transcendence Virtue and Justice of SATPOL PP Bandung showed in their duties performances, promoting a sense of justice, and acknowledges that the strength outside himself, in this case is God Almighty, is more powerful. It made their acts of enforcing the rules considered the existence of other power outside himself which has rules and limits in treating fellow human beings. SATPOL PP Bandung's behavior is difference compared with those in other cities in general which is more aggressive in applying the rules. In the city, although the SATPOL PP should enforce the rules, they rarely do violence to society. This is possible because the role of cultural courtesy, hospitality, and religious communities tend to be strong in Sundanese.

The fifth dominant character is the hallmark of the SATPOL PP Bandung and needs to be optimized so that in carrying out their duties they would not feel comfortable because they do not need to cultivate a new character which is not a part of them.

Detail of each character of training materials are discussed as follows:

Keberagamaan. Keberagamaan or Spirituality is defined as a search on something holy/sacred (Pargament, 1999). This quest can be done through a variety of ways. Someone is telling as spiritual person, as far as they try to discover, know, experience or relate to what they perceive as holy/sacred. People who have a high spirituality will explain the experience or see the situation as the will of God and is associated with better coping efficacy, positive moods, and the purpose of a better life (Mickley, Pargament, Brant \& 
Hip. 1998). In spirituality, we find a way to understand and recognize the powerlessness of human beings and the fact that we have control limits. By having the character of spirituality, we will not rely on the results of mere human abilities, but also expect help from God. Failure to carry out tasks in the way that is fit with the original plan, which may occur especially when we cultivates the fullness. It is believed that the will of God may be different from human desire. Keberagamaan character value of Satpol PP Bandung members after being given training, significantly higher than before the training. This means participants gained a better understanding of the role of spiritual work, including understanding the importance of sincerity in work, fulfilling the needs, to be honest, responsible, committed to the task because it is supposed to work if they rely on God and not to others, such as wealth, position and more. This is also supported by the results of the first phase of the research which shows that the SATPOL PP Bandung members have a high level of patience. They are quite diligent, persistent, and steadfast in work. Patience is related to religious life because they do not expect a reply from the work alone. In other words, the religious character of the members of the SATPOL PP Bandung trainees fully understands the importance of religion in carrying their daily work.

Kebersyukuran. Kebersyukuran is the gratitude and joy in receiving a gift, whether a gift from a certain person or a feeling of peace arising from natural beauty (Peterson \& Seligman, 2005). Gratitude can be personal or transpersonal. Gratitude Personal is directed at a specific person on the advantage given. Gratitude Transpersonal is gratitude to God as the higher power or the cosmos.

Thankful for work means being able to receive tasks assigned happily, willingly, and wholeheartedly. People who are grateful have good souls, big heart, sharp eyes, his heart full of praise to God and recognition of His favor, pleased with his glory, delighted with his kindness, and he always grateful and dhikr to God (Ancok\& Suroso, 2005). Gratitude to God deal with the character of Keberagamaan, wherein if the individual has a high Keberagamaan character, then he will also have the character of grateful to God for what he has earned. Humans show a sense of thankfulness with obedience to the command of his Lord and does not act against Him.
Grateful not only to God Almighty but also for fellow human beings by showing gratitude for what has been obtained is the result of the kindness of others. Gratitude is derived and stimulates moral behavior which will tend to show empathy, sympathy, guilt, and shame (Emmons \& Shelton, 2002). Gratitude to others is also demonstrated by adherence to orders and avoid behavior resisting or disobeying orders. In this study, Satpol PP Bandung have a better understanding after the training. They appreciate what they have earned, including duties, trust, and responsibility that should be run. Gratitude is a powerful incentive to believe that the work should prioritize responsibility, not much to complain, do not despair, and medium to obtain the blessing of God. In addition to the actions taken will involve empathy, sympathy, as well as serving others, not just co-workers but also on target in the field. Thus the aggressive actions can be minimized.

Motivation. Hope is a motivational state that is based on the interaction of the energy that leads to the goal and the way (the plan) in achieving the goals (Snyder, Irving \& Anderson, 1991). By having the character of Motivation/Hope, we will have a clear purpose and constantly looking for ways to achieve that goal. In addition to the character Motivation/ Hope, we will not be easily discouraged, (optimistic) in the face of obstacles as it will continue to look for ways to achieve that goal. Motivation/Hope correlated with active problem solving and attention to the sources of information relating to the problem (e.g., Aspinwall \& Brunhart, 1996; Scheier, Weintraub \& Carver, 1986). Motivation is one character possessed by members of SATPOL PP Bandung. Given the character, Motivation training better understood by members of the SATPOL PP Bandung as a character that should be optimized because of the importance of motivation in a work to perform tasks successfully. They are also more aware that each work should have a clear objective and try to achieve that goal. In addition they know better what to do to increase the motivation of their work when motivation decreases. However, there are still weaknesses perceived by some of the personnel in performing their duties in the field, the motivation decreases when there is no courage to face numerous targets or in the fight for the field goal. It can be anticipated by training other skills, such as persuasion and negotiation abilities. But no less important is 
policies of their supervisor to train martial art to anticipate attacks against them.

Teamwork. This character refers to a person's ability to work with others in a group for a common goal, to collaborate and cooperate (Peterson \& Seligman, 2004). This character is shown to work well as a member of the group, loyal to the group and sharing with others. By having this character, people will be loyal and dedicated, always share and work hard to achieve success of the team; teamwork or cooperation is an important part in carrying out duties as SATPOL PP where the challenges faced in the field often cannot be solved alone when they have to deal with a mass that required a greater number of them. This challenge may even be able to lower their work motivation. Therefore, they should have the character of Teamwork, which utilized both co-workers as well as with other agencies concerned. Teamwork character can be mutually supportive with character motivation which is held as the distinctive character of SATPOL PP Bandung. Given the character, Teamwork training is expected to further increase. With the higher value achieved after the training, they supposed to be more aware and understand the importance of cooperation in performing their duties. They realize that their job is full of challenges both challenges associated with themselves and facing other people The success of their duties are also determined by the importance of cooperating with colleagues. But in this course of Teamwork, participants spend a lot of time to perceive burden of thinking over the years among men-tops and between coworkers. In a discussion among themselves, an understanding eventually gained through free talk of what is desired, especially from subordinates to superiors. Thus, this session may contribute to their understanding of the real cooperation. In the future, the modules can be provided by adding concrete examples that occur in their daily lives.

Justice. Justice means setting aside his own feelings of prejudice. People are just neutral. This character is shown by the ability to conclude anything until they know all the facts and then decide what is right. Justice is an important factor in all the activities included in the work, especially among professionals, as mentioned by Neni Yulianita on the principle of justice "requires a professional to give to anyone what they are entitled." MIMBAR, Vol 18. No.4 (2002). The above quotation shows that justice is not just to treat people equally, but also to fulfill their rights by digging the facts before making a decision. From the statistical test known that a fair understanding of the character has no change after being given training. This is in contrast to the four aspects of the toughness of the others. It seems that the participants do not fully understand the justice that they can do on the field other than the target are treated equally. This is possible because in the rule of justice in carrying out tasks in the field, members of the SATPOL PP Bandung very adhere to orders from above, which may be precisely in contrast to the sense of justice that should also be perceived by the target, in this case, the street vendors. By simply running orders from superiors, does not allow the members of the SATPOL PP Bandung to have decision-making authority other than a policy that has been determined by the superior. It is hard for them to rely on the personal ability to enforce justice, so justice is perceived just as equal treatment as the parties they face in the field, for example in treatment the traders of other street vendors. They perform their tasks without being able to provide a satisfactory alternative to the vendors, in addition to what has been determined by the employer policy. For that, we need a policy assessment on the upper level, as is often perceived in justice street traders with regard to the policies made at the top level. The creation of equitable policies can be done through the implementation of Civic Governance involving community participation, in this case, the vendors. Civic Governance, as summarized by Rahman Mulyawan, is good governance which highlights to the attitudes and behavior of officials in organizing authority as a servant to the citizens. MIMBAR, Vol. 28, No. 2 (December 2012): 157-162. Through Civic models of governance and participatory development, the concept can look for solutions that involve the utilization of the potential problems of society, in this case, the street vendors. Troubleshooting offers tends to come from governments that already have planning or according to urban design before, or is more than the Top Down Bottom Up or derived from the input of the traders. Therefore, justice has not been particularly felt by the street vendors. Moreover, justice concerning equal treatment of hawkers was also often lead to internal conflict among members. This can happen because on the one hand, the members of the SATPOL PP should enforce the rules, on the other hand, they faced the vendors who make a living for the family and there was possibility that these 
merchants are one of their own family. Some of them admitted that it is difficult to be firm in implementing justice in this case. From the observation during the implementation of training materials for Justice, a long discussion occurred, especially about its application to the cases they encounter in the field. Justice concerning working relationships with colleagues is easier to find a solution. Discussion sessions found internal problems where subordinates seem less satisfied with the policies made by the superiors who gave the workloads. In this discussion session, the issue was presented to and responded directly by the employer, and the willingness of the employer to follow up with further clarity and act fairly in the execution of tasks.

But in general, it can be concluded that the training aimed to enhance the understanding of participants about the five characters of character strength. The module can be manufactured by. the material add examples of relevant cases, mainly for the characters of Justice and the additional time for each material in order to hold more indepth discussion.

\section{Conclusions}

There are differences in understanding process between, before, and after the training Character Strength of SATPOL PP Bandung members, namely the character Keberagamaan, Kebersyukuran, Motivation, and Teamwork. The members better understand the role of the character of diversity, Kebersyukuran, Motivation, and Teamwork for fluency in the line of duty. While the character of Justice, which has no significant difference in understanding, seems a little bit hard to understand by the members in the line of duty because they just do the task set by the employer.

Based on the findings above, regarding the absence of differences in understanding the significance of Justice character before and after training, there should be (1) the clarity of the rules of the employer regarding fairness in the distribution and execution of the duties of the members, so there would be no jealousy among members. (2) justice done in the implementation of tasks in the field can be enforced without violence by training the persuasive skills to the members.

\section{Acknowledgement}

Appreciation to Kemenristek Dikti for funding this research through Hibah Bersaing 2016. Thank you also for Satpol PP Bandung for the contribution as respondents in this research.

\section{References}

Ancok, D., Suroso, FN (2005). Islamic psychology. Student Library

Emmons, RA, Shelton, CM (2002). Gratitude and the Science of Positive Psychology. Handbook of Positive Psychology. Oxford University Press.

Mulyawan, R. (2012). Strengthening the 'Civic Governance' through Public Participation in the Process of government management. MIMBAR, Vol. 28, No. 2 (December, 2012): 157-162.

Pargament, KI, Mahoney, A. (2002). Spirituality: Discovering and conserving the Sacred. Handbook of Positive Psychology. Oxford University Press.

Peterson, C., Seligman, (2004). Character Strengths and Virtues: A Handbook and Classification.UK: Oxford University Press.

Seligman, MEP (2002). Authentic Happiness: Creating Happiness with Positive Psychology. Jakarta: PT Mizan Pustaka.

Seligman, MEP (2002). Positive Psychology, Positive Prevention, and Positive Therapy. Handbook of Positive Psychology. Oxford University Press.

Snyder, CR, Rand, KL, Sigmon, DR (2002). Hope Theory: A Member of the Positive Psychology Family. Handbook of Positive Psychology. Oxford University Press.

Yulianita, Neni. (2002). Implementation of Ethics in the Era of Globalization. MIMBAR (Jurnal Sosial dan Pembangunan). Vol 18. No.4. P2U (Pusat Penerbitan Universitas) Publishing Center of the University. 